\title{
The impact of climate change on the ecology of primary plant communities of disturbed habitats
}

\author{
A.N. Belov ${ }^{1}$, N.V. Repsh', ${ }^{2 *}$ D.A. Klyuchnikov ${ }^{2}$, and L.A. Koltsova ${ }^{3}$ \\ ${ }^{1}$ Natural Science Education Department, Far Eastern Federal University, 8 Sukhanova str., the City of \\ Vladivostok, Primorsky Krai, Russia, 690090 \\ ${ }^{2}$ Geography, Ecology and Children's Health Department, Far Eastern Federal University, 8 \\ Sukhanova str., the City of Vladivostok, Primorsky Krai, Russia, 690090 \\ ${ }^{3}$ Far Eastern Federal University, 8 Sukhanova str., the City of Vladivostok, Primorsky Krai, Russia, \\ 690090
}

\begin{abstract}
In this work, the author describes the process of restoration of disturbed ecosystems using various objects as an example, mainly dumps of brown coal deposits. To illustrate the problem, the Rettihovskoye brown coal field of the Primorsky Krai is chosen. The article notes the differences between spontaneous restoration and directed recultivation of the area, describes the characteristics and composition of the new hardy-shrub and herb layer. The basic conditions for self-growth of the study area are determined and the dynamics of the processes in the conditions of changing climatic factors using the observation method over a long period are monitored.
\end{abstract}

The destruction of natural ecosystems can occur for various reasons: 1) natural - the eruption of volcanoes, landslides, dramatic climate change, etc.; 2) anthropogenic deforestation, pasture digression, activities of mining enterprises, soil pollution by technological waste and many other negative impacts.

After removing the pressure of negative factors, a gradual restoration of disturbed ecosystems begins. It can also occur in various ways: with human aid - recultivation, or through spontaneous recovery, especially phytocenosis and edaphocenosis, as the basis of biocenosis. The evolution of vegetation and soil population are parallel, and by the state of one component, one can judge the state of another.

Recultivation is a process associated with large material investments and labor costs, and that is why the restoration percentage of disturbed lands in the Primorsky Krai is extremely low.

The processes of spontaneous restoration of disturbed ecosystems are observed in a much larger volume and are of significant scientific and practical interest. These processes are dependent primarily on climatic conditions - the length of the growing season, its average daily temperature and rainfall. Thus, in regions with a short growing season with low temperatures and little rainfall, the processes of spontaneous restoration of soil cover are extremely slow or not expressed at all. In the context of the Primorsky Krai, in its southern part, in our opinion, such processes have a prospect and only need a little

\footnotetext{
* Corresponding author: repsh_78@mail.ru
} 
adjustment.

To confirm our theory, several observations and studies were carried out at various objects with a disturbed ecosystem structure. Most of the field work was carried out on dumps of brown coal deposits. For objectivity, observations were carried out over a long period of time - 12-15 years. In this case, we were able to track the dynamics of processes in the face of changing climatic factors.

The objects of our study were the dumps and quarries of the Rettihovskoye brown coal deposit. This object is unique because here it is possible to consider both the processes of spontaneous restoration of the soil cover and the processes of transformation of the remediation plantings of Pinus sylvestris L., in accordance with the environmental conditions atypical for this species.

The Rettihovskoye brown coal deposit was discovered in 1956, it was put into development since 1961 and was fully developed in 1991. The mine administration of the Rettihovskoye brown coal mine was liquidated in 1991 [1].

The deposit is located within the Siniy Ridge, which is the western spur of the SikhoteAlin. The Siniy Ridge is the borderline of this mountain system in the west. In the tectonic depressions of the Sikhote-Alin mountain system, extensive deposits of brown and black coal were formed. The main deposits in this system for the Primorsky Krai are Bikinskoye, Pavlovskoye and Artyomovskoye brown coal deposits, Partizanskoye and Razdolnenskoye coal deposits [2]. The Rettihovskiy brown coal mine is located on the territory of the Pavlovskoye brown coal deposit.

Based on geological exploration data, the deposit is divided into two sections: Vostochnaya molda and Zapadnaya molda, at the bottom of which, by 2003, one vast reservoir was formed [3].

According to 2003-2004 data in the process of self-growth, 18 hardy-shrub species of plants and about 15 grassy, mainly ruderal, species were noted [4]. Formation of primary plant communities occurred in various ways. On the steep slopes of the southern exposure, a sparse tree stands of species of the genus Salix L, Populus L., mixed with Nakai and grassy ruderal vegetation appeared. On the central plateau there was a community of herbaceous ruderal plants, which was then destroyed by water and wind erosion, repopulated by woody plants from the ones mentioned above. The woody plants fixed the soil and created conditions for the repeated expansion of grassy ruderal plants. Closed groups of Equisetum arvense L., with rare interspersed species of the genus Artemisia L., Onagra biennis (L.) Skop., Trifolium pretense L., and T. campestre Scheb formed on the gentle slopes of northern exposure. All of the above communities were unsustainable and open. They could not fully resist erosion processes and were on the verge of destruction.

The observations of 2017-2019 showed serious changes in the hydrological regime of the field - the water rose by several meters and significantly increased the total area of the existing water bodies (Fig. 1). This happened due to both an increase in the average annual rainfall (normally $-500-900 \mathrm{~mm}$ ), and an increase in the frequency of summer-autumn monsoon showers. In July, August and September, the average monthly rainfall exceeded the norm by 1.5-3 times. The reason was the increased number and intensity of typhoons (Fig. 2) [5]. 


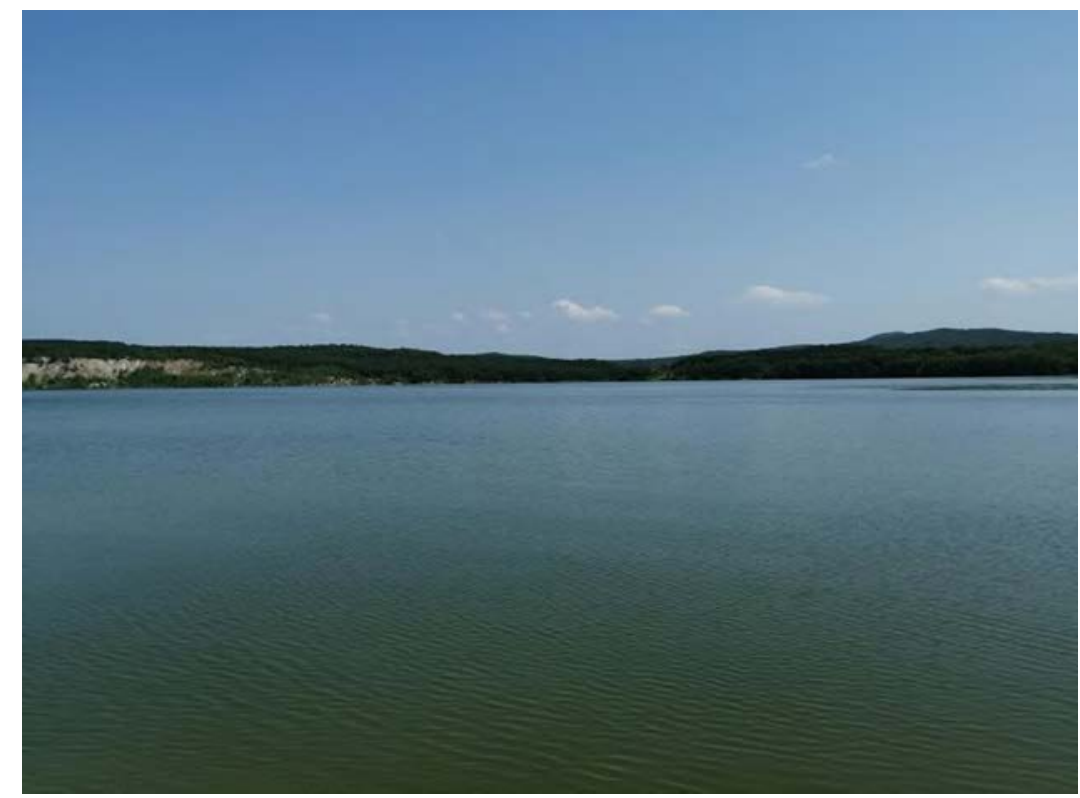

Fig. 1. The current status of the reservoir of the Rettihovskiy quarry (2019)

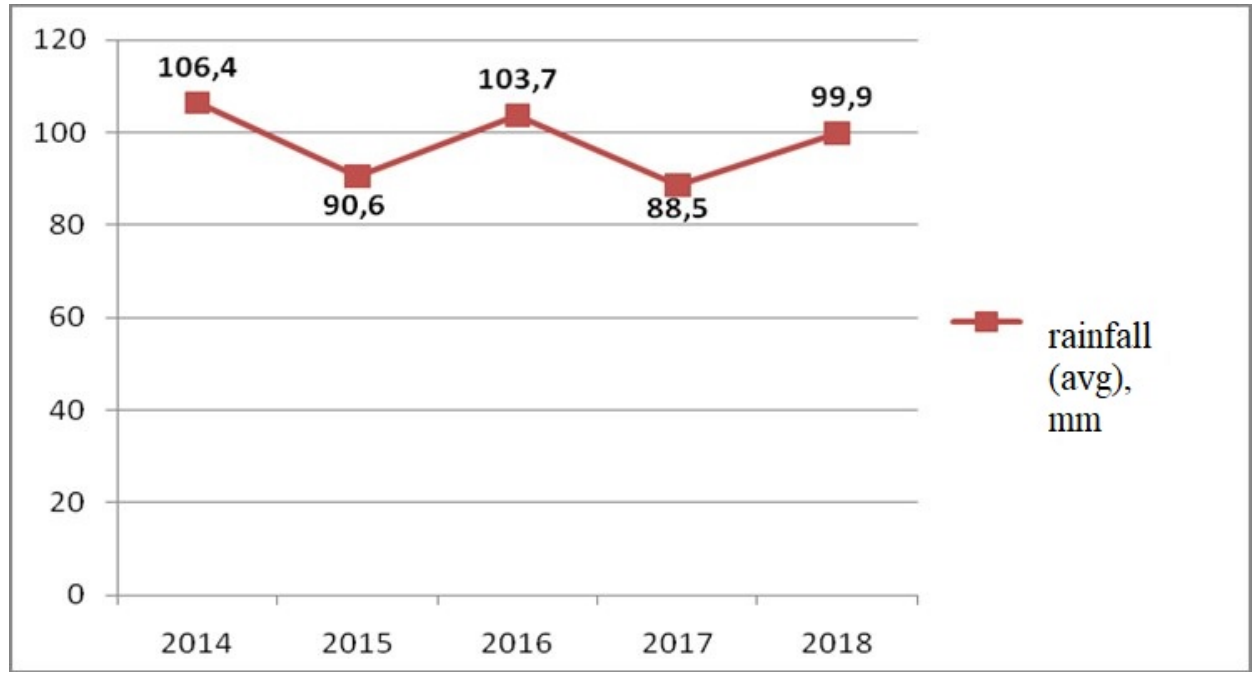

Fig. 2. Average monthly rainfall for the period of 2014-2018 (data from the annual report on the Primorsky Krai environmental situation)

The forest stand in the areas of self-growth has acquired a closed character. In the forest stand, species such as Betula mandshurica Nakia, Populus davidiana Dode and P. koreana Render still prevail. [4]. Some species of Salix caprea L., S. rorida Larsh completely fell out of the stand. (Fig. 3) 


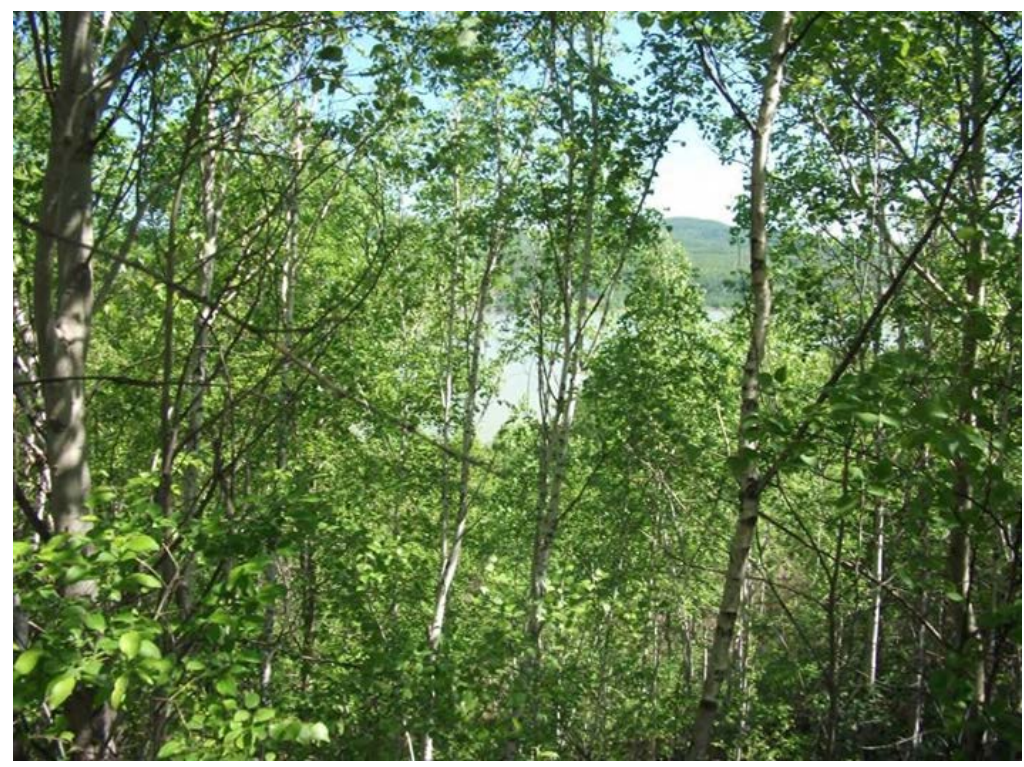

Fig. 3. Formation of a closed stand in areas of self-growth.

The emergence of new species: Padus maackii (Rupr.) Kom., Alnus hirsuta Turcz., Ulmus laciniata (Trautv.) Mayr, Fraxinus mandshurica Rupr., Maackia amurensis Rupr. et Maxim., Acer tegmentosum Maxim., Kalopanax septemlobum (Thunb.) Koidz has been noted. New species also appeared in the shrub layer. - Aser mono Maxim., A. ginnala Maxim., Corylus heterophylla Fish., Euonymus pauciflora Maxim. Earlier shrubs were represented only by Salix caprea L. and Sorbaria sorbifolia (L.) A. Br.

Herbaceous vegetation retained the ruderal composition, but became much less pronounced, thinned. Typical forest species have also appeared - Ranunculus japonicus Thunb. Pyrola subaphylla Maxim., Cacalia hastata L., Serratula coronata L., Artemisia mandshurica Kom. et Alless..

Changes have also occurred in the cultivated areas under the plantings of Pinus silvestris $L$. The linear dimensions of trees have increased significantly due to age, and due to an increase in annual growths because of better moisture supply. Initially, the site was at the top of the quarry and the conditions were extremely xerophytic. The vitality of most trees is average or below average. The pine needles are two-, three-year maximum, there are large areas of chlorosis and necrosis. Seed regeneration of pine is also observed here, which is not typical for Southern Primorye. In plantings, there is an active introduction of Manchurian birch, as well as Populus davidiana Dode and P. nigra L. The presence of undergrowth Kalopanax septemlobum (Thunb.) Koidz, rarely -Aralia mandshurica Rupr. et Maxim and Abies nephrolepis Maxim is noted. From the shrubs - Sorbaria sorbifolia (L.) A. Br. and Rosa davurica Pall. The ground cover is sparse, but more pronounced than in 2004. In lower areas, it is represented mainly by ruderal species. On drier areas, species characteristic of forest ecosystems are found - bushy lichens, Licopodium annotinum L., Dryopteris sp., Carex sp., Pyrola L., Fragaria orientalis Losinsk., Ranunculus japonicas Thunb.

Flooding of the quarry raised the level of groundwater and helped to optimize the water supply to the root systems of the dump vegetation. The increase in the area of water bodies led to the intensification of water evaporation processes, and, consequently, to a local increase in air humidity. This, as well as a decrease in the salt content and acidity of the upper horizons of the soil, under the influence of heavy rainfall, led to the intensification of the processes of vegetation restoration. 
Fundamental changes in the phytomedium can lead both to the restoration of previously existing ecosystems, and to the formation of new unpredictable new plant communities. The emergence of new ecosystems is of certain scientific interest in theoretical and practical value.

\section{References}

1. Feasibility study of the liquidation of Rettikhovskoye OJSC Primorskugol

2. (Vladivostok Publ., 1996), 26 p.

3. Coal mining regions: TOP-7 [Electronic resource]: Dprom.online. Portal for subsoil users. - URL: https://dprom.online/chindustry/regiony-dobychi-uglya-top-7/

4. Geological report on the additional exploration of the East section of the Rettihovskoye brown coal deposit on exploration and operational work as of July 1, 1980: Artyom, Dalvostuglerozvedka Trust Publ. (1980), pp. 14-46.

5. A.N. Belov, S.A. Bersenyova, O.N. Ivus, G.A. Belova. Restoration of ground vegetation covers of disturbed areas on brown-coal dumps in the south of Primorye of Russia. Systematic Reviews in Pharmacy, 11(3), pp. 538 - 543 (2020).

6. Ministry of Natural Resources and Environmental Protection of Primorskiy Krai. Report on the environmental situation [Electronic resource]: The official website of the Government of the Primorskiy Krai and the executive authorities of the Primorskiy Krai. - URL: https://www.primorsky.ru/authorities/executive-agencies/departments/ environment/report-on-the-environmental-situation-1.php 